\title{
DEVELOPMENT OF EDUCATIONAL COMIC "ACCOUNTING DAYS" AS ACCOUNTING LEARNING MEDIA TO IMPROVE STUDENTS LEARNING MOTIVATION
}

\author{
PENGEMBANGAN KOMIK EDUKASI “ACCOUNTING DAYS” SEBAGAI MEDIA \\ PEMBELAJARAN AKUNTANSI UNTUK MENINGKATKAN MOTIVASI BELAJAR SISWA
}

By:

Isfanda Devi Maharani Fijri

Accounting Education Program Yogyakarta State University

isfandadevi@gmail.com

\begin{abstract}
This research aims to: 1) develop educational comic "Accounting Days" as accounting learning media, 2) know the feasibility of educational comic "Accounting Days" as accounting learning media, and 3) examine the improvement of students learning motivation of class XII Social after the development of educational comic "Accounting Days". The research was conducted using Four-D model which consists of define, design, develop, and disseminate. The data collection technique was observation, interview, and questionnaires. Based on the analysis of students learning motivation average score, there is an increase in Students Learning Motivation's average score from 3,21 to 3,40 . However, the result of paired sample $\mathrm{T}$ test analysis shows that there is not any significant change in Students Learning Motivation after using Educational Comic "Accounting Days". Thus, Educational Comic "Accounting Days" as Accounting Learning Media is not proven to improve Students' Learning Motivation of class XII Social SMA Negeri 5 Yogyakarta Academic Year of 2017/2018.
\end{abstract}

Keyword: Learning Media, Accountng, Educational Comic, Learning Motivation

\begin{abstract}
Abstrak
Penelitian ini merupakan penelitian pengenmbangan. Penelitian ini bertujuan untuk: 1) mengembangkan Komik Edukasi “Accounting Days" sebagai media pembelajan akuntansi, 2) mengetahui kelayakan komik edukasi "Accounting Days" sebagai media pembelajaran akuntansi, 3) mengetahui peningkatan motivasi belajar siswa kelas XII IPS setelah menggunakan komik edukasi "Accounting Days" sebagai media pembelajaran. Penelitian ini dilakukan menggunakan model Four-D yang terdiri dari tahap define, design, develop, dan disseminate. Teknik pengambilan data pada penelitian ini menggunakan observasi, wawancara, dan kuesioner. Analisis motivasi belajar siswa pada treatment group, menunjukkan bahwa terdapat peningkatan rata-rata skor motivasi belajar siswa yang sebelumnya 3,21 menjadi 3,40. Dengan demikian, media pembelajaran komik edukasi "Accounting Days" tidak dapat meningkatkan Motivasi Belajar Siswa secara signifikan pada kelas XII IPS SMA Negeri 5 Yogyakarta Tahun Ajaran 2017/2018.
\end{abstract}

Kata kunci: Media Pembelajaran, Akuntansi, Komik Edukasi, Motivasi Belajar. 


\section{INTRODUCTION}

Education is a process of communication in transferring knowledge, values, and skills that take place inside or outside the educational institutions and passed down from generation to generation through teaching, training, and research. Education is humane symptoms and conscious attempts that associated with students, teachers, educational interaction, environment and facilities of education (Siswoyo, 2013:54). The success of the learning process is the main factor in achieving the purpose of education.

Learning strategies is one of the factors that teachers have to observe in teaching and learning processes. According to Uno (2011: 9), there are four criteria of learning strategies, (1) learning strategies orientation on the learning task, (2) learning strategies relevant to the learning materials, (3) instructional techniques used in learning strategies, and (4) learning media used in learning strategies. The example of the fourth criteria of learning strategies is using the right learning media when teacher delivers materials to students.

The learning media collaborates cognitive, affection, and psychomotor aspects which very important in the learning processes (Arsyad, 2011: 75). The learning media can increase and direct students' attention to the learning process, so it can increase students' learning motivation. According to Sardiman (2011: 75), Learning Motivation is a stimulant in students that create, ensure continuity, and provide direction on learning activities to achieve learning's purpose.

The observation made in Class XII Social SMA Negeri 5 Yogyakarta, showed that the Students' Motivation toward Accounting subject was still low. This can be seen from the behavior of the students when the teacher taught accounting material in the class. Almost $60 \%$ of students tended to be busy with other activities compared to learn accounting book in class. Students also feel bored and sleepy when the teacher taught accounting material in class. This showed that the students' interest in studying accounting subject was low. Accounting Learning Media used by teacher were textbook and exercise which made students feel bored easily. Therefore, Class XII Social SMA Negeri 5 Yogyakarta requires attractive learning media that can bring up Students' Learning Motivation on Accounting subject.

Learning Media is a technology that can be used by teachers for learning purposes. Learning media is a physical tool to deliver the subjects (Rusman, 2012: 170). According to Rosi and Breidle in Sanjaya (2011: 163) stated that learning media is all the instruments and the elements that can be used to achieve the purpose of education such as radio, television, books, newspaper, magazine, etc. The use of an appropriate learning media on learning process can increase Students Learning Motivation about the lessons that have been taught.

Based on an interview with some students in Class XII Social, students prefer learning by using teaching materials that show visual, non-standard language, and simple material explanations. The students also tend to be interested in reading picture book than a textbook, this because picture book has a coherent storyline and easy to remember. Based on students conditions above, one of learning media that can be used is comics.

Waluyanto (2005: 51) stated that a comic is a form of visual communication media that has the power to deliver information and easily understood by the reader. Sudjana (2013: 63) defined comic as a form of the cartoons which reveals the characters as a story in the explanation which is linked with the picture and designed to provide the reader with entertainment. There are several developments of comic as a learning media, such as the educational comic.

Educational comic is a comic that convey the learning message through words 
and images that arranged coherently to describe a story. The development of educational comic "Accounting Days" as accounting learning media is adjusted with the condition of class XII Social SMA Negeri 5 Yogyakarta.The material used in this Educational Comic "Accounting Days" is the Financial Statements of trading company and adjusted with the syllabus used in SMA Negeri 5 Yogyakarta.

In addition, the development of educational comic as learning media is selected because there is still no development of educational comic media in SMA Negeri 5 Yogyakarta. This research is expected to produce educational comic products that can make accounting learning more interesting and it can facilitate learners in understanding accounting materials. Educational comic are also expected to motivate students to learn accounting subject independently.

\section{RESEARCH METHOD \\ Design of Research}

This research is a research and development (R\&D) type. Sugiyono (2014: 297) stated that the research and development $(\mathrm{R} \& \mathrm{D})$ is a research method used to produce current products and test effectiveness of the products.

The development of Educational Comic "Accounting Days" as Learning Media using a Four-D model developed by Thiagarajan and Semmel in Mulyatiningsih (2012: 179-183). There are four steps in this Four-D development research there are Define, Design, Develop, and Disseminate.

\section{Place and Time of Research}

This research conducted at SMA Negeri 5 Yogyakarta is located in Jalan Nyi Pembayun39, Kotagede, Yogyakarta. This research conducted in January until February 2018. While the reporting stage will be carried out in February until April 2018.

\section{Research Subject and Object}

The subject in this research is 24 students of Class XII Social 1, and 24 students of Class XII Social 2 SMA Negeri 5 Yogyakarta which selected based on the observation result about Students Learning Motivation in Accounting Subject. In addition, another subject of this research are material expert, media expert, and accounting teacher of class XII Social SMA Negeri 5 Yogyakarta,. The object in this research is the Development of Educational Comic "Accounting Days" as Learning Media for the students of class XII Social SMA.

\section{Research Procedures}

The procedure of this research adapted Four-D model developed by Thiagarajan (Mulyatiningsih, 2013: 195) which consists of 4 stages of development, there are as follows:

1. Define stage

This stage has a purpose to establish and defines the terms of learning media development. Definition stage consist of four steps, as follows:

a. Curriculum Analysis

Curriculum analysis has a purpose to determine the competence of developed learning media. This analysis is done by analyzing the curriculum-rate used in Class XII Social SMA Negeri 5 Yogyakarta, and analyzing core competency (KI) and basic competency (KD) that will be uside in developed learning media.

b. Students Characteristics Analysis

This analysis has a purpose to know the characteristics of students who used Educational Comic learning media.

c. Material Analysis

Material analysis is done by identifying the material that will be used in Educational comic, and selecting the material that suitable 
with students condition. The material that will be used in Educational Comic "Accounting Days" is Financial Statements of Trading Company

d. Specifying Instructional Objectives This stage has a purpose to limit the researcher to not deviate from the original purpose of developing Educational Comic. The purpose of developing Educational Comic "Accounting Days" is to improving Students Learning Motivation on Accounting Subject.

2. Design stage

This stage has a purpose to prepare the initial design of developed learning media. This stage consists of three steps, as follows:

a. Media Selection

Media selection is used to determine the proper media in the presentation of learning materials. The media that selected in this research is Comic.

b. Format Selection

Format selection is used to determine the proper format that suitable with developed learning media.

c. Initial Design

Intitial design is the steps of making developed learning media.

3. Development stage

This stage consists of experts' appraisal and developmental testing The purpose of this stage is to develop learning media that has been revised based on experts' appraisal. This stage consist of two steps, as follows:

a. Experts' Appraisal

Experts' appraisal is a technique to validate or assess the feasibility of designed product. The experts consist of material expert, the media expert and Accounting Learning Practitioner in SMA Negeri 5 Yogyakarta. b. Developmental Testing

Developmental Testing is designed product testing on real subject. Developmental testing of Educational Comic "Accounting Days" will be done in Class XII Social SMA Negeri 5 Yogyakarta

4. Disseminate stage

Disseminate stage is the stage of using Educational Comic "Accounting Days" as learning media on a research subject to measure Students' Learning Motivation after using developed learning media. This stage consists of two steps, there are as follows:

a. Validation Testing

Validation testing is done to measure the improvement of Students Learning Motivation of Class XII Social after using Educational Comic "Accounting Days" as Accounting Learning Media.

b. Packaging, Adoption, and Diffusion

After validation testing, Educational Comic is package and ready to be disseminated as accounting learning media for students.

\section{Data Collection, and Data Analysis}

\section{Technique}

1. Data Collection Technique

Data collection technique used in this research is questionnaire. There are two types of questionnaire used in this research. (1) Questionnaire about feasibility of Educational Comic "Accounting Days". This questionnaire was used to gather feasibility data of educational comic "Accounting Days" from material expert, media expert, accounting learning practitioner, and students. (2) Students Learning Motivation questionnaire. This questionnaire was used to collect the response of students learning 
motivation before and after using educational comic "Accounting Days".

2. Data Analysis Technique

Data analysis technique used in this research are (1) qualitative descrpitive analysis used to process the data in form of critism, suggestion, from material expert, media expert, and accounting learning practitioner validation, also from students respond. (2) quantitative descripitive analysis used to process the data from product validation questionnaire by material expert, media expert, and accounting learning practitioner. The analysis steps were (1) processing the questionnaire score by creating scoring criteria, (2) calculating mean score for each indicators of questionnaires, and (3) converting mean scores of questionnaire. This analysis also used to process the data from Students Learning Motivation questionnaire. The analysis steps were (1) processing the questionnaire score by creating scoring criteria, (2) calculating mean score for each indicators of questionnaires, and (3) converting mean scores of questionnaires. The analysis of Students Learning Motivation also done by using correlated " $T$ " test. This analysis had a purpose to know the improvement of Students Learning Motivation after using educational comic "Accounting Days".

\section{RESEARCH RESULTS AND DISCUSSION}

The procedures used in this research are adaptation and modification of Four-D research model which developed by Tiagharajan and Semmel in Mulyatiningsih (2013: 195-199). The procedure consists of 1) Define, 2) Design, 3) Develop, and 4) Disseminate. These research procedures are described as follows:

1. Define Stage
Define stage in this research was done by several steps, as follows:

a. Curriculum Analysis

Researcher conducted an analysis of syllabus as a guide in using the material in the development of Educational Comic "Accounting Days" as Accounting Learning Media. The material used in the development of Educational Comic "Accounting Days" was financial statements of trading company with the basic competence of preparing the financial statements of trading company.

b. Students Characteristics Analysis Educational Comic "Accounting Days" as learning media was expected to be able to meet the needs of students of class XII Social SMA Negeri 5 Yogyakarta as accounting learning media that interesting, practical and easy to understand for students. In addition, the development of learning media also expected to improve students' learning motivation of class XII Social SMA Negeri 5 Yogyakarta in accounting subject.

c. Material Analysis

Educational

Comic

"Accounting Days" as learning media was expected to be able to meet the needs of students of class XII Social SMA Negeri 5 Yogyakarta as accounting learning media that interesting, practical and easy to understand for students. In addition, the development of learning media also expected to improve students' learning motivation of class XII Social SMA Negeri 5 Yogyakarta in accounting subject.

d. Specifying Instructional Objectives Educational Comic "Accounting Days" as learning 
media was expected to be able to meet the needs of students of class XII Social SMA Negeri 5 Yogyakarta as accounting learning media that interesting, practical and easy to understand for students. In addition, the development of learning media also expected to improve students' learning motivation of class XII Social SMA Negeri 5 Yogyakarta in accounting subject.

2. Design Stage

a. Media Selection

Media selection in this developed media was adjusted with the need analysis that had been done in definition stage. Based on need analysis, the selection learning media by the researcher was a learning media in form of Educational Comic entitled "Accounting Days".

b. Format Selection

The detail of the format used in developing Educational Comic "Accounting Days" is presented in Table 1 as follows:

Table 1. The Format of Educational Comic "Accounting Days"

\begin{tabular}{|c|l|}
\hline Design & \multicolumn{1}{|c|}{ Description } \\
\hline Form & $\begin{array}{l}\text { Books with A5 size full- } \\
\text { color printed, cover using } \\
\text { ivory paper, and contents } \\
\text { using HVS 80 grams paper }\end{array}$ \\
\hline Material & $\begin{array}{l}\text { Financial Statements of } \\
\text { Trading Company }\end{array}$ \\
\hline Portion & $\begin{array}{l}\text { Preliminary: foreword, and } \\
\text { characters introduction } \\
\text { content: material } \\
\text { presentation } \\
\text { cover: developer profile }\end{array}$ \\
\hline Function & $\begin{array}{l}\text { As accounting learning } \\
\text { media in the class or outside } \\
\text { the class }\end{array}$ \\
\hline
\end{tabular}

c. Initial Design

The developed learning media in form of Educational Comic "Accounting Days" was designed with an attractive display and understandable language.

Educational Comic "Accounting Days" as Accounting Learning Media contains financial statements of trading company material. The purpose of the development of Educational Comic "Accounting Days" as accounting learning media was to improve Students Learning Motivation on financial statements of trading company material.

3. Development Stage

This stage aimed to produce a revised developed learning media based on advice from experts. This stage consists of several steps, there are as follows:

a. Experts' Appraisal

The validation of Educational Comic "Accounting Days" as Accounting Learning Media conducted by one material expert, one media expert, and one accounting teacher. Material expert and media expert validation conducted by lecturers of Accounting Education Department, Faculty of Economics, Yogyakarta State University, while accounting learning practitioners validation conducted by accounting teacher of Class XII Social SMA Negeri 5 Yogyakarta.

Experts' appraisal of Educational Comic "Accounting Days" as Accounting Learning Media had a purpose to know the feasibility of Educational Comic "Accounting Days" as Accounting Learning Media in improving Students Learning Motivation. The summary of validation by material 
expert, media expert, and accounting learning practitioner can be seen in Table 2 as follows:

Table 2. Recapitulation of Experts Validation

\begin{tabular}{|c|l|c|c|}
\hline No & \multicolumn{1}{|c|}{ Description } & $\begin{array}{c}\text { Mean } \\
\text { Score }\end{array}$ & Category \\
\hline 1. & Material expert & 4.78 & $\begin{array}{l}\text { Strongly } \\
\text { Feasible }\end{array}$ \\
\hline 2. & Media expert & 4.20 & Feasible \\
\hline 3. & $\begin{array}{l}\text { Accounting } \\
\text { Learning } \\
\text { Practitioner }\end{array}$ & 4.04 & Feasible \\
\hline
\end{tabular}

Based on Table 2, the mean score from material expert was 4.78. the mean score lies in the interval $\bar{X} \geq 4.2$, the mean score of material expert validation of developed learning media is in "Strongly Feasible" category. The mean score from media expert was 4.20. the mean score lies in interval $\bar{X} \geq 3.4$, thus the mean score of media expert validation is in "Feasible" category. The mean score of accounting learning practitioner validation was 4.04. The mean score lies in interval $\bar{X} \geq$ 3.4 thus the mean score of accounting learning practitioner validation of developed media was in "Feasible" category. Based on table 1, it concluded that educational comic "Accounting Days" was feasible to be used in developmental testing with the students.

b. Developmental Testing

Developmental testing was done by using the revised of Educational Comic "Accounting Days". The subject of this developmental testing was 24 students of class XII Social SMA Negeri 5 Yogyakarta. The instrument used in developmental testing is students respond questionnaire. The result of developmental testing can be seen in Figure 1 as follows:

\section{Students' Responded in Developmental Testing}

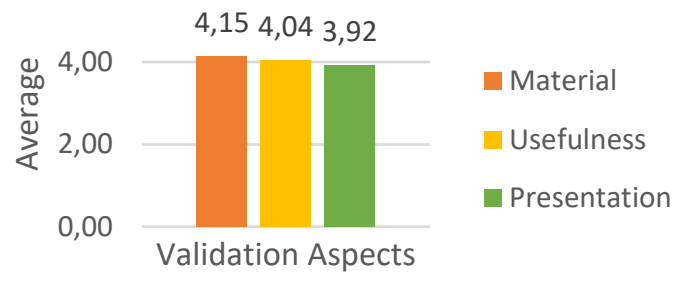

Figure 1. Diagram of Students' Responded in
Developmental Testing

Figure 1 showed that the mean score of material aspect was 4.15 included in "Feasible" category, the mean score of usefulness aspect was 4.04 included in "Feasible" category, and the mean score of presentation aspect was 3.92 included in "Feasible" category.

Based on developmental testing, it can be seen that all students were able to understand Financial Statements on trading company material which is presented in Educational Comic "Accounting Days". Students responded positively to Educational Comic "Accounting Days". There was nothing to be revised in the presentation of Educational Comic "Accounting Days", so this developed media can be used in disseminate stage.

4. Disseminate Stage

This stage aimed to implement the develop learning media to measure the Students' Learning Motivation in research subjects. This stage consists of two steps, there are as follows:

a. Validation Testing 
Validation testing was done to know the improvement of Students' Learning Motivation after using Educational Comic "Accounting Days" as Accounting Learning Media and to know the effectiveness of Educational Comic "Accounting Days" on improving Students Learning Motivation. The data of validation testing were tested using the analysis of mean score of Students' Learning Motivation and Paired Sample T-Test. There are described as follows:

1) The mean score of Students' Learning Motivation

The Recapitulation of Students' Learning Motivation average score is presented in Figure 2 as follows:

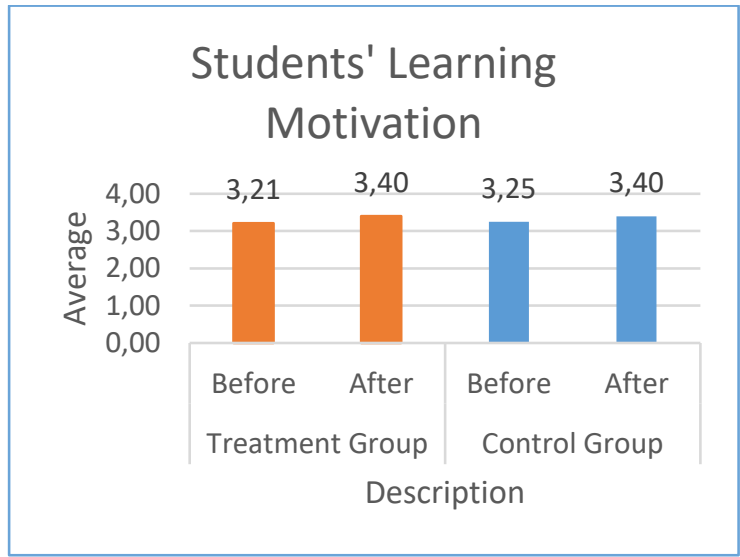

Figure 2. Diagram of Validation Testing on Students' Learning Motivation

Based on Figure 2, it can be seen that the mean score Students' Learning Motivation in of treatment group after using Educational Comic is 3,40 . The mean score is higher than the mean score of Students' Learning Motivation in treatment group before using Educational Comic, while the mean score of Students' Learning Motivation in control group after using Educational Comic also higher than the mean score of Students' Learning Motivation before using Educational Comic.

2) Paired Sample T Test

The result of Paired Sample $\mathrm{T}$ Test is presented in Table 3 as follows:

Table 3. Paired Samples T-Test of Students' Learning Motivation in Treatment Group and Control Group

\begin{tabular}{|c|c|c|c|c|c|}
\hline & \multicolumn{2}{|c|}{ Mean } & \multirow{2}{*}{} & \\
\cline { 2 - 6 } & $\begin{array}{c}\text { Treat } \\
\text { ment } \\
\text { Grou } \\
\mathrm{p}\end{array}$ & $\begin{array}{c}\text { Control } \\
\text { Group }\end{array}$ & Sig. & T & $\begin{array}{c}\text { Sig (2- } \\
\text { tailed) }\end{array}$ \\
\hline $\begin{array}{c}\text { Bef } \\
\text { ore }\end{array}$ & 64,21 & 64,92 & $\begin{array}{c}0,4 \\
49\end{array}$ & $\begin{array}{c}0,4 \\
51\end{array}$ & 0,656 \\
\hline $\begin{array}{c}\text { Aft } \\
\text { er }\end{array}$ & 68,04 & 68,04 & $\begin{array}{c}0,0 \\
00\end{array}$ & 0,0 & 1,000 \\
00 & & \\
\hline
\end{tabular}

Table 3 showed that mean score of Students' Learning Motivation in treatment group before using Educational Comic is 64,21, while the mean score of Students' Learning Motivation in control group before using Educational Comic is 64,92 . The $t_{\text {count }}$ is 0,451 with sig $(p)$ $=0,656$. Table 3 also showed that the mean score of Students' Learning Motivation in treatment group after using Educational Comic is 68,04 while the mean score of Students' Learning Motivation in control group after using Educational Comic is 68,04. 
The $t_{\text {count }}$ is 0,000 with sig $(p)$ $=1,000$.

Based on this analysis, it is known that at significant level of $5 \%$ there isn't any significant different of Students' Learning Motivation in treatment group and control group before using Educational Comic "Accounting Days" as Accounting Learning Media and at significant level of 5\%, there isn't any significant different in Students' Learning Motivation in treatment group and control group after using Educational Comic. Based on this result, it can be concluded that there isn't any significant changes of Students Learning Motivation of Class XII Social SMA Negeri 5 Yogyakarta after using Educational Comic "Accounting Days".

b. Packaging, Diffusion, and Adoption

Dissemination stage in this research and development was done by disseminate developed media through a limited distribution of teacher and students. The purpose of this distribution was to obtain a response and feedback on developed media. If the limited user response was good, then it would be distributed in large quantities. In this research, the product that had been developed are distributed to all students of class XII Social, Accounting teacher and to Library of SMA Negeri 5 Yogyakarta.

\section{CONCLUSION AND SUGGESTION Conclusion}

Based on the findings of the research and discussion that had been described, it could be concluded that the Development of Educational Comic "Accounting Days" is not proven to Improve Students Learning Motivation of Class XII Social SMA Negeri 5 Yogyakarta Academic Year of 2017/2018.

\section{Suggestion}

Based on the research findings, the researcher gave suggestions as follows:

1. For teacher, Students Learning Motivation on Accounting subject will increase if the media used by the teacher not only focused on books, printed modules, and worksheets. Educational Comic "Accounting Days" can be used as an alternative Accounting Learning Media. The teacher is expected to always develop an interactive and creative learning media so students have higher learning motivation to learn Accounting subject.

2. For school, The school is expected to facilitate the teacher to participate in the development of learning media training. The school also expected to improve learning media facilites to support the process of Accounting Learning in school.

3. For further research, Educational Comic "Accounting Days" can be tested using larger samples for better quality. Further research also can be done by developing learning media with interesting characters and use attractive display, so it can make students interest to study financial statement of trading company topic by improving the topics in the story of Educational Comic. 


\section{REFERENCES}

Arsyad, A. (2006). Media Pembelajaran. Jakarta: Raja Grafindo.

Rusman, dkk. (2012). Pembelajaran Berbasis Teknologi Informasi dan Komunikasi. Jakarta: Rajawali Pers.

Sanjaya, W. (2011). Strategi Pembelajaran Orientasi Dasar Pendidikan. Jakarta: Penanda Media.

Sardiman. (2011). Interaksi dan Motivasi Belajar Mengajar. Jakarta: Rajawali Pers.

Siswoyo, D. (2013). Ilmu Pendidikan. Yogyakarta: UNY Press.

Uno, H.B. (2011). Teori Motivasi dan Pengukurannya: Analisis di Bidang Pendidikan. Jakarta: Bumi Aksara.

Sudjana, N \& Ahmad, R. (2013). Media Pengajaran. Bandung: Sinar Baru Algesindo.

Waluyanto, H.D. (2005). Komik sebagai Media Komunkasi Visual Pembelajaran. Nirmana, 7, 45-55. 